\title{
The Growth Response of Quercus dentata Sapling to the Environmental Gradients Treatment
}

\author{
Sang-Kyoung Lee, Young-Han You and Hoonbok Yi ${ }^{1}$ *
}

Department of Biology, Kongju National University, Gongju 314-701, Korea

${ }^{1}$ Division of Environmental \& Life Science, Seoul Women's University, Seoul 139-774, Korea

Received March 20, 2010 /Accepted April 12, 2010

\begin{abstract}
Quercus dentata (Thunb. ex Murray) is a major tree found in dry habitats such as limestone areas of Korea. In order to characterize the ecological traits of $Q$. dentata, we treated $Q$. dentata saplings under four gradient levels of major environment factors such as light, soil moisture and nutrients for 5 months in a glass house. We then measured and analyzed growth differences among them. Regarding light, aboveground, belowground and plant biomass were highest at a high gradient and lowest at a low one. The root/shoot ratio was highest at the highest light gradient. Regarding moisture, no measured items were significantly affected by the moisture gradient. Regarding nutrients, aboveground, belowground and plant biomass were the highest at a slightly high gradient and the lowest at a gradient lower or higher than this. The root/shoot ratio was not significantly affected by the nutrient gradient. From these results, it was shown that the growth of $Q$. dentata was more affected by light and nutrients in the environment than moisture.
\end{abstract}

Key words : Quercus, ecological trait, environmental treatment

\section{서 론}

참나무속(Quercus)은 너도밤나무과(Fagaceae)에 속하는 상 록 또는 낙엽성의 교목 및 관목으로 동북아시아 전역을 포함 한 온대지방에 약 400 500종이 분포하고 있다[18,25].

우리나라에서 참나무가 자라는 곳은 사양토이며 배수가 양 호한 변성암 지역에 분포한다[20]. 참나무는 산에서 순림 또는 혼효림을 이루고[5], 활엽수 중 가장 넓은 분포범위를 가지며 생육이 비교적 빠르다[21]. 그리고 우리나라에서 참나무는 전 체 임목 축적량의 $27 \%$ 를 점유하고 있는 수종으로 삼림의 생태 적인 측면에서 매우 중요한 종이지만 잡목으로 인식되어 그 가치를 인정받지 못하였다[17].

우리나라의 낙엽성 참나무속(Genus Quercus)에는 떡갈나 무(Quercus dentata), 상수리나무(Q. acutissima), 굴참나무 $(Q$. variabilis), 신갈나무(Q. mongolica), 졸참나무(Q. serrata) 그리 고 갈참나무 $(Q$. aliena $)$ 등 6 분류군과 자연교잡종의 12 분류군이 있다[19]. 이 6종의 낙엽성 참나무는 한반도 중부 이남에 집중 되어 분포한다[12].

본 연구대상인 떡갈나무는 낙엽활엽교목으로 전국 표고 $800 \mathrm{~m}$ 이하의 산기슭, 산중턱뿐 아니라 해변가의 야산이나 섬 에도 잘 생육하며[16], 건조한 석회암 지역에서 우점종으로 분 포하고 있다[13,14]. 떡갈나무의 최적 수직분포대는 $300 \mathrm{~m}$ 내 외이고[11], 주로 저지대에 분포하는 lower oak에 속한다[34].

*Corresponding author

Tel : +82-2-970-5668, Fax : +82-2-970-5974

E-mail : yih@swu.ac.kr
떡갈나무는 참나무속의 다른 종에 비해 잎이 가장 넓고 열매 를 싸는 비늘이 가장 길며 줄기는 곧게 자라 수형을 이루고, 내조성이 강하며 토심이 깊은 비옥한 토양이 적지이나 건조한 곳에서도 생육이 양호하고 또한 각종 공해에도 잘 견디며[16], 다른 참나무종에 비해 내음성이 약하다[22]. 뿐만 아니라 떡갈 나무는 생육이 빠르며 산불에도 강하고 그루터기의 움싹과 뿌리에 의해 빠르게 재생한다[25].

식물의 생육은 광, 수분 그리고 영양소와 같은 여러 환경 요인들에 의하여 제한을 받는다 $[3,30,33]$. 또한 식물은 이러한 환경 요인들에 대하여 반작용(reaction)함으로써 적응한다 [26]. 유식물은 환경에 대한 반응에 있어서 성숙한 식물보다 더 민감하여 환경에 대한 식물의 반응을 연구하기에 적합하다 $[31,4]$.

국내에서 떡갈나무(군락)를 대상으로 한 연구에는 맹아발 생력 및 맹아생장량[21], 성장 및 물질생산[29], 삼림토양의 환 경요인 및 효소활동 비교분석[32], 피음에 따른 잎, 줄기 그리 고 뿌리의 생장변화[8], 침수토양에서 생육변화[9], 건조스트 레스에 대한 기공저항의 조절과 전략의 분화[15] 등이 있다. 그러나 아직까지 떡갈나무 한 종을 대상으로 실내에서 통제된 조건의 광, 수분 그리고 영양소 등의 환경요인을 동시에 처리 하여 생육반응을 비교 분석한 연구는 없는 실정이다.

따라서 본 연구는 떡갈나무의 생태적 특성을 밝히기 위하여 식물 생육에서 가장 중요하게 생각되는 광, 수분 그리고 영양 소를 온실에서 떡갈나무의 유식물에 각각 처리하여 그 생육 반응을 관찰하고 분석하였다. 


\section{재료 및 방법}

\section{종자 선정 및 발아}

본 실험에 사용한 유식물은 국내에 자생하는 떡갈나무 $(Q$. dentata)이고 그 종자는 경기도 고양시 야산에서 2007년 10월 에 채집한 뒤 $4^{\circ} \mathrm{C}$ 에서 냉장보관 하였다. 이듬해인 2008년 5월 에 크기가 유사한 종자를 선별하여 지름 $24 \mathrm{~cm}$, 높이 $23.5 \mathrm{~cm}$ 인 화분에 2 개씩 파종하였으며 각 구배당 4 개씩 총 48 개의 화분을 사용하였다.

\section{환경요인의 구배}

실험에 처리한 환경 요인은 식물 분포에 일반적으로 가장 중요하다고 알려진 광, 수분 그리고 영양소[2]를 각각 4 구배로 처리하였고, 온도 구배는 계절에 따른 변화를 처리하기 어렵 기 때문에 고려하지 않았다.

광 구배는 유리온실에 입사되는 전 일광 $100 \%$ (L4, 구배 4, 13,000 15,000 lux)를 기준으로 70\% (L3, 구배 3, 9,100 10,500 lux), 30\% (L2, 구배 2, 3,900 4,500 lux)와 10\% (L1, 구배 1, 1,300 1,500 lux)가 되게 차광막의 두께를 조절하여 만들었다. 이때 광 구배는 조도계(TES-1332A)를 사용하여 측 정하였다.

수분 구배는 포장용수량인 $700 \mathrm{ml}$ 를 기준으로M4 (구배 4) 로 하여 $500 \mathrm{ml}$ 를 M3 (구배 3), $300 \mathrm{ml}$ 를 $\mathrm{M} 2$ (구배 2) 그리고 $100 \mathrm{ml}$ 를 $\mathrm{M} 1$ (구배 1)로 각각 4 구배로 나누어 3 4일 간격으로 공급하였다.

토양의 유기물 구배는 야외에서 일반적인 유기물 함량인 $5 \%$ 를 기준으로 건조 토양에 비율을 4 구배로 나누어 $0.5 \%$ ( $\mathrm{N} 1$, 구배 1), $2 \%$ (N2, 구배 2), 5\% (N3, 구배 3) 그리고 10\% (N4, 구배 4)가 되도록 배합하여 사용하였다. 배합한 유기물은 유기 질비료(주, 효성오엔비)를 사용하였다.

\section{수확 및 측정}

각 유식물은 환경요인을 2008년 5월부터 9월까지 5개월 동안 환경이 조절되는 온실에서 처리한 후 수확하였다. 측정 항목은 지상부 무게(aboveground biomass: 줄기 무게+잎 무게), 지하 부 무게(belowground biomass: 뿌리무게) 그리고 식물체 무게 (plant biomass: 지상부 무게+지하부 무게)이다. 유식물은 물로 세척하여 토양을 완전히 제거하여 잎, 줄기 그리고 뿌리로 나누 어 $70^{\circ} \mathrm{C}$ 에서 건조시킨 후 전자저울 $(\mathrm{UX} 400 \mathrm{H}, \mathrm{SHIMADZU})$ 을 사용하여 건중량을 측정하였다. 이렇게 얻어진 자료는 Fisher 의 최소유의차 법으로 $5 \%$ 유의수준에서 차이를 검정[28] 하였 고, Statistica 통계패키지를 이용하였다.

\section{결과 및 고찰}

광 처리구에서 떡갈나무의 지상부 무게는 전일광의 $70 \%$ 의
광조건인 L3 $(1.65 \mathrm{~g}, 323 \%)$ 에서 가장 높았고, L1 $(0.51 \mathrm{~g}, 100 \%)$, 전일광의 $30 \%$ 인 L2 $(0.54 \mathrm{~g}, 105 \%)$ 에서 가장 낮았고, 전일광의 $10 \%$ 인 L4 $(1.42 \mathrm{~g}, 278 \%)$ 에서 그 중간이었다(p<0.05, Fig. 1). 지하부 무게는 L3 $(2.56 \mathrm{~g}, 400 \%)$ 와 L4 $(3.58 \mathrm{~g}, 559 \%)$ 에서 높았 고, L1 $(0.64 \mathrm{~g}, 100 \%)$ 과 L2 $(0.83 \mathrm{~g}, 127 \%)$ 처리구에선 낮았다. 식물체 무게는 L3 $(4.21 \mathrm{~g}, 362), \mathrm{L} 4(5.00 \mathrm{~g}, 431 \%)$ 에서 높았고, L1 $(1.16 \mathrm{~g}, 100 \%), \mathrm{L} 2(1.37 \mathrm{~g}, 118 \%)$ 에서 낮았다.

본 연구에서는 떡갈나무는 광이 적은 조건보다 광이 많은 조건에서 잘 자란 것을 알 수 있었다[22]. 광 구배가 $100 \%$ (L4) 에서 $10 \%$ (L1)로 감소할 때 지상부, 지하부 그리고 식물체 무 게가 각각 $65 \%, 83 \%$ 와 $77 \%$ 의 비율로 감소하였는데, $\mathrm{Ha}[8]$ 의 연구에서는 각각 $81 \%, 86 \%$ 와 $83 \%$ 의 비율로 감소하여 그 경향 성이 동일하였지만 그 정도의 차이는 있었다. 본 연구결과에 서는 지상부, 지하부와 식물체 무게의 가장 낮은 광 $\left(\mathrm{L}_{\mathrm{L}}: \mathrm{L} 1\right)$ 에 대한 가장 높은 광 $\left(\mathrm{L}_{\mathrm{H}}: \mathrm{L} 4\right)$ 의 비 $\left(\mathrm{L}_{\mathrm{H}} / \mathrm{L}_{\mathrm{L}}\right)$ 는 각각 $2.7,5.5$ 와 4.3 이 었는데, 높은 광의 비에 대한 낮은 광의 비 $\left(\mathrm{L}_{\mathrm{H}} / \mathrm{L}_{\mathrm{L}}\right)$ 로 측정한 신갈나무의 지상부, 지하부와 식물체 무게는 각각 $2.0,4.1$ 과 3.0으로 나타났으며, Baek [1]의 연구와 경향성이 동일하였다. Jeong 등[10]의 연구에 의하면 상수리나무와 굴참나무의 지상 부, 지하부와 식물체 무게는 광이 높을수록 생장률이 높은 경 향을 보여 본 연구 결과와 유사하였다. 그리고 Jeong 등[10]의 연구에서 신갈나무의 지하부와 식물체 무게는 광이 높을수록 잘 자라는 경향을 보여 본 연구 결과와 유사하였지만, 지상부 무게는 구배 간 생육의 차이가 없어 본 연구 결과와 차이가 있었다.

수분 처리구에서 떡갈나무의 지상부 무게는 $\mathrm{M} 1(1.50 \mathrm{~g}$, $100 \%)$, M2 (1.63 g, 108\%), M3 (1.04g, 69\%) 그리고 M4 (1.09

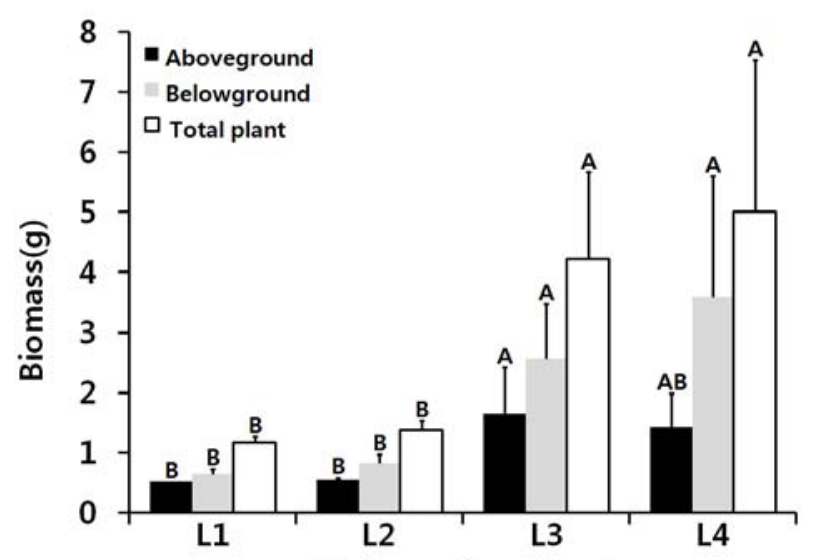

Light gradient level

Fig. 1. Aboveground, belowground and plant weight of the saplings of $Q$. dentata along with light treatments. Light state 1 (L1) is the lowest and state 4 (L4) is the highest level. In light condition, moisture $700 \mathrm{ml}$ and nutrient $5 \%$ was equally treated. Alphabets on the bars mean the statistically significant difference among light gradient levels (Fisher's least significant difference, $p<0.05$ ) 
$\mathrm{g}, 72 \%)$ 에서 거의 차이가 없었다( $\mathrm{p}<0.05$, Fig. 2). 지하부 무게 는 M1 (3.56 g, 100\%), M2 (4.23g, 118\%), M3 (2.43 g, 68\%) 그리고 $\mathrm{M} 4(2.54 \mathrm{~g}, 71 \%)$ 로 $\mathrm{M} 2$ 에서 가장 높았고, $\mathrm{M} 3$ 에서 가장 낮은 경향으로 나타났지만 그 차이는 통계학적으로 유의성이 없었다(p>0.05). 식물체 무게는 M1 (5.06 g, 100\%), M2 (5.87 $\mathrm{g}, 116 \%), \mathrm{M} 3(3.47 \mathrm{~g}, 68 \%)$ 그리고 $\mathrm{M} 4(3.63 \mathrm{~g}, 71 \%)$ 로 $\mathrm{M} 2$ 에서 가장 높았고, $\mathrm{M} 3$ 에서 가장 낮은 것으로 나타났지만 통계적인 유의성이 없었다( $\mathrm{p}>0.05)$.

이것으로 볼 때 떡갈나무의 지상부, 지하부 그리고 식물체 무게는 수분에 영향을 크게 받지 않는다는 것을 알 수 있었고, 이 결과는 뿌리가 잠기는 침수토양에서 잎 무게, 줄기 무게, 뿌리 무게 그리고 식물체 무게의 생육차이가 없다고 밝힌 [9] 의 연구 결과와 유사하였다. 그리고 떡갈나무를 건성생육지종 으로 분류한 [15]의 연구와 건조한 석회암 지역에 분포한 $[13,14]$ 의 연구를 비교해 보면 떡갈나무는 수분이 부족한 조건 에서도 잘 자랄 수 있을 것으로 생각된다. [10]의 연구에서 굴 참나무와 신갈나무의 지상부, 지하부와 식물체 무게는 구배 간 생육의 차이가 없어 본 연구 결과와 일치하였다. 그리고 [10]의 연구에서 상수리나무의 지상부 무게는 구배 간 생육의 차이가 없어 본 연구 결과와 일치하였지만, 지하부와 식물체 무게는 수분 구배가 중간일 때 잘 자라 본 연구 결과와 달랐다. 따라서 떡갈나무는 상수리나무보다 생육을 하는 동안 수분의 영향을 덜 받는 것으로 생각된다.

유기물 처리구에서 떡갈나무의 지상부 무게는 건조 토양의 부피를 기준으로 유기질비료 $0.5 \%$ 의 처리구인 N3 $(2.03 \mathrm{~g}$, $225 \%)$ 에서 가장 높았고, $2 \%$ 의 N1 $(0.90 \mathrm{~g}, 100 \%), 5 \%$ 의 N2 $(0.91 \mathrm{~g}, 101 \%), 10 \%$ 의 $\mathrm{N} 4(1.10 \mathrm{~g}, 122 \%)$ 에서 낮았다 $(\mathrm{p}<0.05$, Fig. 3). 지하부 무게는 N3 (6.08 g, 207\%)에서 가장 높았고,

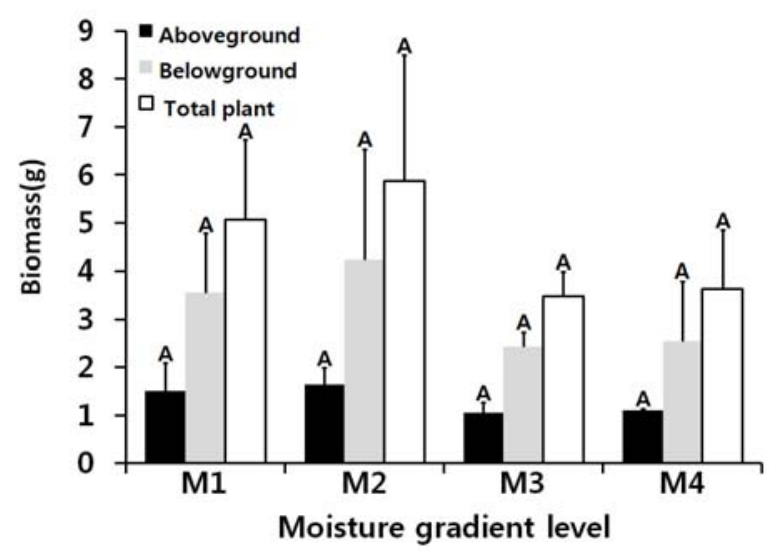

Fig. 2. Aboveground, belowground and plant weight of the saplings of $Q$. dentata along with moisture treatments. Moisture state 1 (M1) is the lowest and state 4 (M4) is the highest level. In moisture condition, light $100 \%$ and nutrient $5 \%$ was equally treated. Alphabets on the bars mean the statistically significant difference among moisture gradient levels (Fisher's least significant difference, $p<0.05)$.
$\mathrm{N} 1(2.93 \mathrm{~g}, 100 \%), \mathrm{N} 2(3.11 \mathrm{~g}, 106 \%)$ 와 N4 $(3.20 \mathrm{~g}, 109 \%)$ 에서 낮았다. 식물체 무게는 N3 $(8.11 \mathrm{~g}, 246 \%)$ 에서 가장 높았고, $\mathrm{N} 1(3.29 \mathrm{~g}, 100 \%), \mathrm{N} 2(4.02 \mathrm{~g}, 122 \%)$ 와 N4 (4.31 g, 131\%)에서 낮았다.

광 처리구에서 떡갈나무의 지하부/지상부 비(root/shoot ratio)는 L4 $(2.47,197 \%)$ 에서 L1 $(1.25,100 \%)$, L2 $(1.51,120 \%)$, L3 $(1.67,133 \%)$ 보다 훨씬 높았다(p<0.05, Fig. 4). 본 연구에서 떡갈나무의 지하부/지상부 비는 광 $100 \%$ 에서 광 $10 \%$ 로 감소 할 때 $49 \%$ 가 감소하였는데 [9]의 연구는 $24 \%$ 가 감소하여 그 경향성은 동일하였지만 본 연구보다 적게 감소하였다. [10]의 연구는 광 $100 \%$ 에서 광 $10 \%$ 로 감소할 때 신갈나무, 상수리나 무와 굴참나무의 지하부/지상부 비가 각각 $49 \%, 67 \%$ 와 $74 \%$ 가 감소하여 본 연구 결과와 그 경향성이 유사하였지만 굴참 나무와 상수리나무는 비율이 더 급감하였다. 이것으로 볼 때 그늘이 지는 조건에서 떡갈나무는 굴참나무와 상수리나무보다 지하부에 더 많은 투자를 하는 것으로 판단된다. 그리고 떡갈나 무의 지하부/지상부 비는 채페럴 관목(Chaparral shrub)의 약 $0.3[7,24]$ 이나 열대우림 수종의 0.25 0.7[6]보다 더 높았다.

떡갈나무의 수분 처리구에서 지하부/지상부 비는 $\mathrm{M} 1$ (2.44, 100\%), M2 (2.44, 100\%), M3 (2.36, 96\%)와 M4 (2.34, $95 \%)$ 로 거의 차이를 보이지 않은 결과(p<0.05, Fig. 4$)$ 를 나타 냈다. 이는 [1]의 연구결과인 졸참나무와 굴참나무의 지하부/ 지상부 비는 수분 구배 간에 차이를 보이지 않았던 것은 본 연구 결과와 일치하였다. 그러나 신갈나무는 수분이 감소하면 서 지하부/지상부 비가 감소하여 본 연구 결과와 달랐다. 본 연구는 수분이 적은 조건에서 지하부/지상부 비가 높은 경향 을 보였다. 이는 수분이 가장 많은 조건에서 굴참나무와 신갈

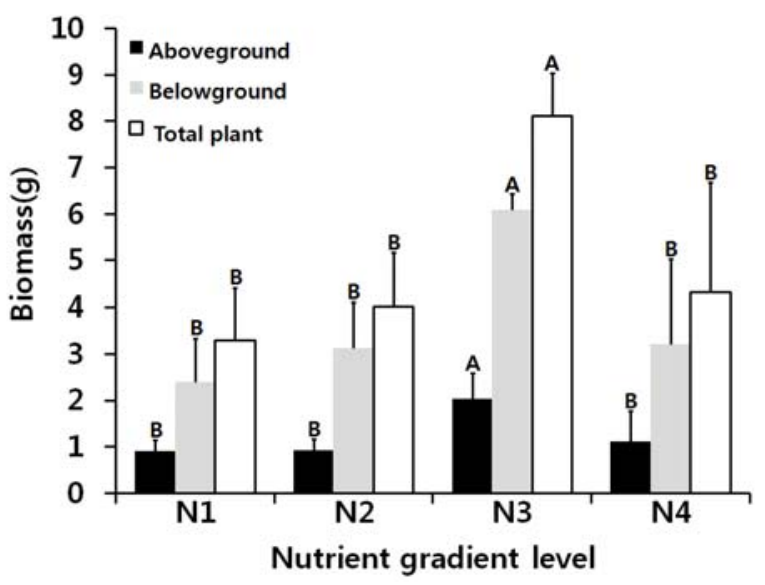

Fig. 3. Aboveground, belowground and plant weight of the saplings of $Q$. dentata along with nutrient treatments. Nutrient state 1 (N1) is the lowest and state 4 (N4) is the highest level. In nutrient condition, light $100 \%$ and moisture $700 \mathrm{ml}$ was equally treated. Alphabets on the bars mean the statistically significant difference among nutrient gradient levels (Fisher's least significant difference, $p<0.05)$. 


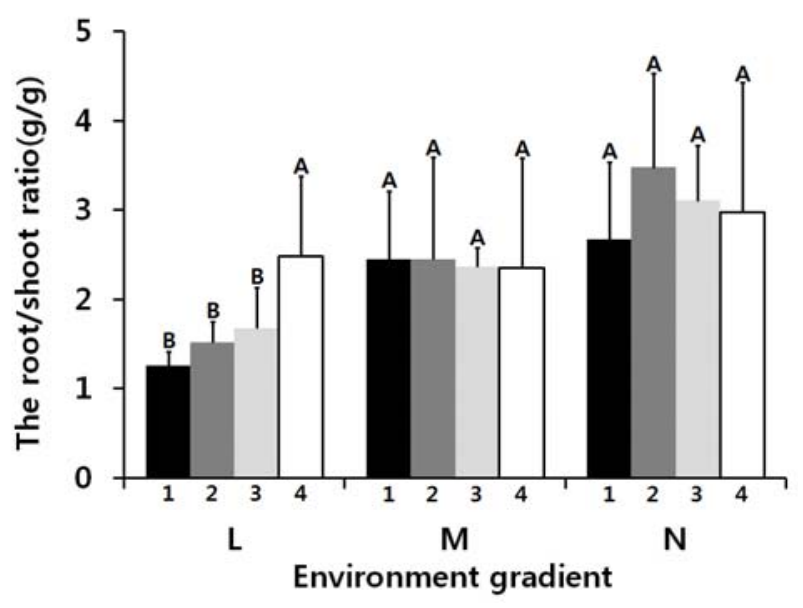

Fig. 4. The root/shoot ratio of the saplings of $Q$. dentata along with light, moisture, and nutrient treatments. Light $(\mathrm{N})$, moisture (M) and nutrient $(\mathrm{N})$ state 1 is the lowest and state 4 is the highest level. Alphabets on the bars mean the statistically significant difference among gradient levels (Fisher's least significant difference, $p<0.05$ )

나무의 지하부/지상부 비가 가장 높은 경향을 보인 [10]의 연 구 결과와 다소 차이가 있었다. 그리고 [23]의 연구는 북아메리 카의 참나무 14 종 중 습윤한 토양에 서식하는 참나무가 중습 성과 건조한 토양에서 서식하는 참나무보다 지하부에 적게 투자를 한다고 밝힌바 있다.

떡갈나무의 유기물 처리구에서 지하부/지상부 비는 N1 $(2.66,100 \%), 2 \%$ 의 $\mathrm{N} 2(3.47,130 \%), 5 \%$ 의 N3 $(3.10,116 \%)$ 와 $10 \%$ 의 N4 $(2.97,111 \%)$ 로 거의 차이를 보이지 않았다 $(\mathrm{p}<0.05$, Fig. 4). 이러한 경향은 유기물 함량이 $2 \%(\mathrm{~N} 2)$ 인 조건에서 상 수리나무의 지하부/지상부 비가 높았던 [10]의 결과와 유사하 였다. 그러나 [10]의 연구에서 굴참나무와 신갈나무는 $2 \%$ 인 조건에서 지하부/지상부 비가 낮아서 본 연구 결과와 달랐다. 그리고 [1]의 연구에서 신갈나무의 지하부/지상부 비는 유기 물 구배에 의해 영향을 받지 않았는데 졸참나무와 굴참나무는 유기물이 감소할수록 지하부/지상부 비가 증가하였다. 본 연 구에서, 떡갈나무의 지상부, 지하부 그리고 식물체 무게는 건 조 토양의 부피를 기준으로 유기물이 $5 \%$ 인 조건에서 잘 자란 다는 것을 알 수 있었다. 떡갈나무가 가장 잘 자란 N3의 유기 물 함량은 $5 \%$ 인데 이는 야외에서 흔히 발견할 수 있는 양으로 [27]의 연구에서도 굴참나무림의 전체 평균 유기물 함량이 N3 의 조건에 가까운 $6.51 \%$ 이었다. 그러나 $[13,14]$ 의 연구에서는 떡갈나무가 분포하는 석회암 지역의 유기물 함량은 $10 \%$ 이상 으로 본 연구 결과보다 높았다[35]. [10]의 연구는 상수리나무 의 지상부에서는 생육의 차이가 없었고, 지하부와 식물체 무 게 그리고 굴참나무와 신갈나무의 지상부, 지하부와 식물체 무게는 유기물 함량이 많을 때(N3, N4)보다 유기물 함량이 가장 적을 때(N1) 더 높아서 본 연구 결과와 상반 되었다. 이는 종에 따라 생육에 적합한 유기물 함량의 차이가 있다는 것을
알 수 있고, 본 연구대상인 떡갈나무는 다른 3종의 참나무보다 유기물 함량이 풍부한 곳에서 잘 자라는 것으로 판단된다[22].

본 연구 결과를 종합해보면 떡갈나무는 광량이 많고, 유기물 량이 비교적 많은 조건에서 잘 자라는 것으로 판단되며 수분에 의해서는 영향을 크게 받지 않는 것으로 판단된다. 즉, 떡갈나 무의 분포는 수분보다는 광이나 토양의 영양소에 의해 영향을 받는 다는 것을 의미한다. 그러나 본 연구만으로 떡갈나무의 생육에 적합한 환경 조건을 단정하기는 어렵다. 따라서 떡갈나 무의 생태적 특성을 좀 더 알기 위해서는 더 다양한 환경요인 을 고려한 구배처리에 대한 연구가 수행되어야 할 것이다.

\section{감사의 글}

본 연구는 환경부의 2009년 장기생태연구(LTER), 국토해양 부의 자연과 함께하는 Eco-River(2008-2009)의 사업의 일환으 로 수행되었습니다.

\section{References}

1. Baek, M. S. 1995. A comparison of the establishment and growth of seedlings among three Quercus species. Master's Thesis, Catholic University, Seoul, Korea.

2. Barbour, M. G., J. H. Burk, and W. D. Pitts. 1987. Terrestrial plant ecology. 2nd eds., The Benjamin. Cummings Publishing Company.

3. Brand, D. G. 1991. The establishment of boreal and sub-boreal conifer plantation: an integrated analysis of environmental conditions and seeding growth. For. Sci. 37, 68-100.

4. Burton, P. J. and F. A. Bzzaz. 1991. Tree seeding emergence on interactive temperature and moisture gradients and in patches of old-field vegetation. Am. J. Bot. 78, 131-149.

5. Chung, D. K. and K. H. Min. 1990. A study on the relative decay durability for development of utilization of Quercus species. Educational Research Journal, Univ. of Konkuk, Seoul, Korea 13, 9-21.

6. Fetcher, N., B. R. Strain, and S. F. Oberbauer. 1983. Effects of light regime on the growth, leaf morphology and water relations on seedlings of two species of tropical trees. Oecologia 58, 314-319.

7. Gulmon, S. L. and C. C. Chu. 1981. The effects of light and nitrogen on photosynthesis, leaf characteristics and dry matter allocation in the Chaparral shrub, Diplaucus aurantiacus. Oecologia 58, 314-319.

8. Ha, S. H. 1989. Performance and photosynthesis of seedlings of several Quercus plant grown under the different light intensities. Master's Thesis, Seoul National University, Seoul, Korea.

9. Han, S. J., J. H. Kim, and Y. H. You. 2009. Selection on tolerant oak species to water flooding for flood plain restoration. Korean J. Wetl. Soc. 11, 1-7.

10. Jeong, H. M., H. R. Kim, and Y. H. You. 2009. Crowth difference among saplings of Quercus acutissima, Q. variabilis and 
Q. mongolica under the environmental gradients treatment. Korean J. Environ. Biol. 27, 82-87.

11. Jeong, T. H. and Y. C. Lee. 1965. A study of the Korean woody plant zone and favorable region for the growth and proper species. Collection of Thesis, Sungkyunkwan University, Seoul, Korea 10, 329-366.

12. Kim, C. M., K. W. Kwon, and H. K. Moon. 1985. Variation of leaf form of leaf variabilities of natural population of Quercus spp. Korean J. For. Soc. 71, 82-89.

13. Kim, J. H., H. T. Moon, and Y. S. Kwak. 1990. Community structure of soil properties of the Pinus densiflora forests in limestone areas. Korean J. Ecol. 13, 285-295.

14. Kim, J. H., H. T. Moon, and Y. S. Kwak. 1991. Community structure and soil properties of Chinese Cork oak(Quercus variabilis) forests in limestone area. Korean J. Ecol. 14, 159-169.

15. Kim, J. W. and J. H. Kim. 1994. Stomatal control and strategy segregation to drought stress in young trees of several oak species. Korean J. Ecol. 17, 241-249.

16. Korea Forest Research Institute. 1987. Illustrated woody plants of Korea. Korea Forestry Service, Seoul, Korea.

17. Korea Forest Research Institute. 1989. Studies on the development and utilization of Korean oak resources(II). pp. 3-4, Ministry of Science and Technology, Seoul, Korea.

18. Kubitzki, K. 1993. Fagaceae. pp. 301-309, In Kubitzki, K., J. Rohwer, and V. Bittrich (eds.), The families and genera of vascular plants. Vol. II. Flowering Plants. Dicotyledons: Mongoliid, Hamamelid and Caryophyllid Families. Springer-Verlag, Berlin, Heidelberg.

19. Lee, C. B. 2003. Coloured flora of Korea. pp.197-210, Hyangmunsa, Korea.

20. Lee, D. K., K. I. Kwon, Y. H. Kim, and Y. S. Kim. 2000. Sprouting and sprout growth of four Quercus species $(Q$. mongilica, $Q$. variabilis, $Q$. acutissima and $Q$. dentata). Korean J. For. Energy 19, 61-68.

21. Lee, C. S., W. K. Lee, J. H. Yoon, and C. C. Song. 2006. Distribution pattern of Pinus densiflora and Quercus Spp. sta nd in Korea using spatial statistic and GIS. Korean J. For. 95, 663-671.

22. Lim, J. H. 1995. An oak and our culture. pp.125-126,
Soomoon, Korea.

23. Long, T. J. and R. H. Jones. 1996. Seeding growth strategies and seed size effect in fourteen oak species native to different soil moisture habitats. Trees 11, 1-8.

24. Mahall, B. E. and W. H. Schlesinger. 1982. Effects of irradiance on growth, photosynthesis and water use efficiency of seedlings of the Chaparral shrub, Ceanothus megacarpus. Oecologia 54, 291-299.

25. Menitsky, Yu. L. 2005. Oaks of Asia. Pp. 90, Science publishers, Inc., Enfield, New Hampshire.

26. Mooney, H. A., W. E. Winner, and E. J. Pell. 1991. Response of plants to multiple stresses. Academic Press, Inc.

27. Namkung, J. 2010. Production and nutrient cycling in the Quercus variabilis forest at Mt. Worak. Ph. D. Thesis, Kongju National University, Gongju, Korea.

28. No, H. J. and H. Y. Jeong. 2002. The statistical analysis in which it is easy to know by statistica. pp.336-345, Hyungseul, Seoul, Kerea.

29. Park, I. H., D. K. Lee, K. J. Lee, and G. S. Moon. 1996. Growth, biomass and net production of Quercus species. Korean J. For. Soc. 85, 76-83.

30. Phares, R. E. 1971. Growth of red oak (Quercus rubra) seeding in relation to light and nutrients. Ecology 52, 669-672.

31. Racinc, C. H. 1971. Reproduction of three species of oak in relation to vegetational and environment gradients in the southern Blue Ridge. Bull. Torrey Botanic. Club 98, 297-310.

32. Song, I. G. and Y. K. Choi. 1997. Comparison of enzyme activities and environmental factor between the forest soil of two species in the family, Quercoideae. Korean J. Environ. Bio. 15, 131-139.

33. Walter, H. 1973. Vegetation of the earth: in relation to climate and the Eco-physiological 1 Condition. Springer-Verlag, New York.

34. Wang, C. W. 1961. The forest of China with a survey of grassland and desert vegetation. pp. 75-93, Harvard University, Cambridge, Massachusetts.

35. Yi, H. B., S. H. Nam, and J. H. Kim. 2007. Transfer of calcium along trophic levels on limestone and Granitic Gneiss grassland. Korean J. Environ. Biol. 25, 228-238.

\section{초록 : 환경구배처리에 따른 떡갈나무의 생육 반응}

이상경 · 유영한 · 이훈복 ${ }^{\star}$

(공주대학교 생물학과, ${ }^{1}$ 서울여자대학교 환경생명과학부)

떡갈나무는 우리나라의 건조한 석회암 지역에 서식하는 주요한 교목이다. 본 연구는 떡갈나무의 생태적 특성 을 밝히기 위하여 생육에 주요한 영향을 미치는 광, 수분 그리고 유기물 등의 환경요인을 각각 4 구배로 하여 온실 에서 유식물에 처리하여 생육반응을 관찰하고, 분석하였다. 광 구배에서 지상부, 지하부 그리고 식물체 무게는 높은 조건에서 잘 자랐고, 낮은 조건에서 못 자랐다. 지하부/지상부 비는 가장 높은 조건에서 제일 높았다. 수분 구배에서 모든 측정 항목에서 구배에 따른 생육의 차이가 없었다. 유기물 구배에서 지상부, 지하부 그리고 식물체 무게는 약간 높은 조건에서 잘 자랐고, 이보나 낮거나 높은 조건에서 못 자랐다. 이상으로 볼 때 떡갈나무의 생육 은 수분 조건보다는 광 조건과 유기물 조건에 의하여 더 큰 영향을 받는 것으로 나타났다. 